\title{
Primary results of 2-dimensional electrophoresis for protein studies of Gentiana kurroo Royle somatic embryos derived from long-term embryogenic cell suspensions
}

\author{
Agnieszka Niedziela', Jan Jarosław Rybczyński* \\ 1 Department of Plant Physiology and Biochemistry, Plant Breeding and Acclimatization Institute - National Research Institute, Radzików, 05-870 Błonie, Poland \\ ${ }^{2}$ Department of Experimental Plant Biology, Botanical Garden - Center for Biological Diversity Conservation of the Polish Academy of Sciences in Powsin, Prawdziwka 2, 02-973 Warsaw, Poland
}

\begin{abstract}
Two-dimensional gel electrophoresis was used to compare protein expression profiles between various stages of Gentiana kurroo Royle somatic embryos. Seven distinct stages (I-VII) were pointed out and measured from long-term embryogenic cell suspension. Isoelectric focusing was done in the $\mathrm{pH}$ intervals 3-10, and the second dimension was carried out with $13 \%$ SDS-polyacrylamide gel electrophoresis. Dependent on the stage from about 400 (stage IV) to more than 700 (stage II) protein spots were totally detected. The molecular weight of abundant proteins range from 12 to $70 \mathrm{kDa}$, however, majority of proteins were located between $20-49 \mathrm{kDa}$ spots on the gels. The highest difference in the number of spots appeared in the case of globular embryo (stage I) and elongated cotyledonary stage (stage VII) with differences being about 130 spots. The relevance of embryogenic cell suspension choice for proteomic analysis as well as expediency of the increasing number of particular embryo stages is discussed.
\end{abstract}

Keywords: Gentiana kurroo; two-dimensional gel electrophoresis; protein studies; embryogenic cell suspension

\section{Introduction}

Gentianaceae family consists about 1700 species, but only 28 are the object of plant tissue culture and biotechnology. The first papers summarizing achievements of gentian plant tissue cultures were published in 1988 and 1991 $[1,2]$. Since then, considerable progress in the biochemistry and biotechnology of the genus has been achieved. The very first paper showed possibilities to establish plant multiplication of Gentiana kurroo by culturing the shoot tips and nodal segments on Murashige and Skoog (MS) medium supplemented with BAP (benzylaminopurine) and NAA (naphtaleneacetic acid) [3]. For most effective rooting, individual shoots with 3-4 nodes were implanted on hormone-free agar MS medium supplemented only with $6 \%$ sucrose [3]. Randomly amplified polymorphic DNA and karyotypic analysis showed the lack of the variation and genetic stability of regenerants and confirmed efficacy of the protocol for micropropagation of G. kurroo over a ten-year period [4]. The significant progress in vegetative plant cell manipulation was recognized when the somatic embryogenesis of primary explants for a few gentian species was described [5]. Among the studied gentians, G. kurroo

\footnotetext{
*Corresponding author. Email: jjryb@obpan.pl
}

Handling Editor: Elżbieta Bednarska-Kozakiewicz appeared very embrygenic with tremendous morphogenic potential since seedling and leaf explants [6] were used for culture initiation. Furthermore, once established cell suspensions [7] appeared to be an excellent source of embryogenic cells and their protoplasts [8]. Cell suspensions also created embryogenic aggregates and somatic embryos [9]. Somatic embryogenesis is a complex developmental process that offers multidisciplinary studies of embryogenesis and great potential in plant propagation. Since two-dimensional electrophoresis (2-DE) was developed the application of the method has been increasingly used as a tool for studies of somatic embryogenesis [10-12]. It should be stressed that proteomic study in gentians has not been published until now, with the exception of one describing isoenzymes and protein patterns in leaves of in vitro micropropagated plantlets of G. lutea in the presence of various combination of plant growth regulators [13].

The aim of this paper is to show the primary results on the newly discovered proteomic changes between various stages of G. kurroo somatic embryos.

\section{Material and methods}

Somatic embryos were selected from hypocotyl derived suspension culture (Fig. 1a) described previously [7] and used for protein isolation and detection (Fig. 2). Different 
stages of development were regenerated spontaneously in one conical flask (Fig. 1b,c). The scale of typical four stages of zygotic embryogenesis was replaced with seven in vitro stages scale. The following stages were identified: I - globular embryo; II - heart with thick epidermis and differentiated rootlet; III - an elongated embryo with well-differentiated primary root; IV - cotyledonary embryo with closed cotyledons; V - cotyledonary embryo with detached cotyledons 2-3 mm in size; VI - cotyledonary embryo 3-4 mm; VII - cotyledonary embryos larger than $5 \mathrm{~mm}$ in size.

Protein extraction from $10 \mathrm{mg}$ of tissue was performed using an extraction buffer ( $0.7 \mathrm{M}$ sucrose, $0.5 \mathrm{M}$ Tris, $30 \mathrm{mM}$ $\mathrm{HCl}, 50 \mathrm{mM}$ EDTA, $10 \mathrm{mM} \mathrm{KCl}, 2.0 \mathrm{mM}$ PMSF, $13 \mathrm{mM}$ DTT) and a resolving buffer (9.0 M urea, $4 \%$ Nonidet NP-40, $2 \%$ Servalyte, $\mathrm{pH} 2-4$. Two-dimensional gel electrophoresis performed according to Hochstrasser et al. [14]. In the first dimension, isoelectrofocusing (IEF), $1 \times 150 \mathrm{~mm}$ capillary was used for polymerization a polyacrylamide column gel with Servalyte $\mathrm{pH} 3-10$. The IEF was conducted at room temperature for $18 \mathrm{~h}(50-1000 \mathrm{~V})$. Protein were separated in the second dimension (SDS-PAGE) in $13 \%$ polyacrylamide slabs $(1 \times 150 \times 150 \mathrm{~mm})$. After electrophoresis, the peptides were stained with silver nitrate according to Heukeshoven and Dernick [15]. Protein spots on gels were measured with Image Master 2-D Elite LKB software.

\section{Results and discussion}

The paper presents second field of our experimental activity with the application both embryogenic cell suspension and its proteomic studies. Two-dimensional gel electrophoresis has been successfully engaging in proteome studies of encapsulated embryogenic cell suspension during its adaptation to osmotic stress in cryopreservation protocol of Gentiana cruciata [16]. In these studies, more attention was paid for description of dynamics of the electrophoretic proteomic profile changes considering proteins that showing upstream growth of activity and other proteins being in the decreasing activity.
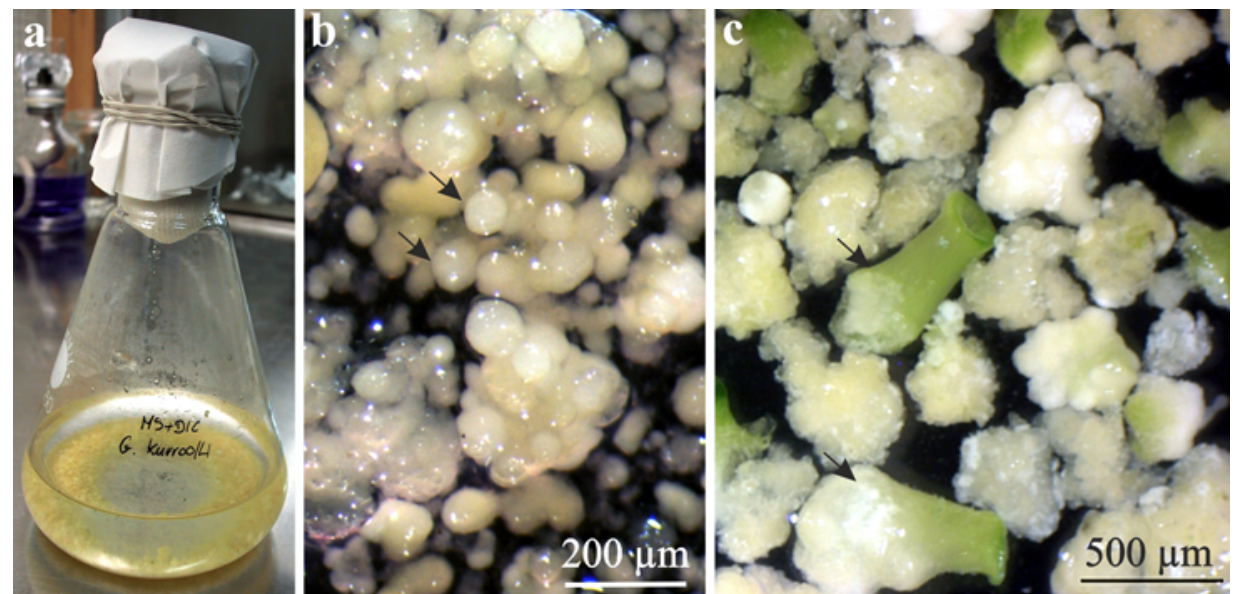

Fig. 1 Established embryogenic cell suspension of Gentiana kurroo: 80-ml cell suspension carried on in 200-ml conical flask - the source of studied material (a); embryos in globular $(\mathbf{b})$, and cotyledon stage (indicated by arrows; $\mathbf{c}$ ).

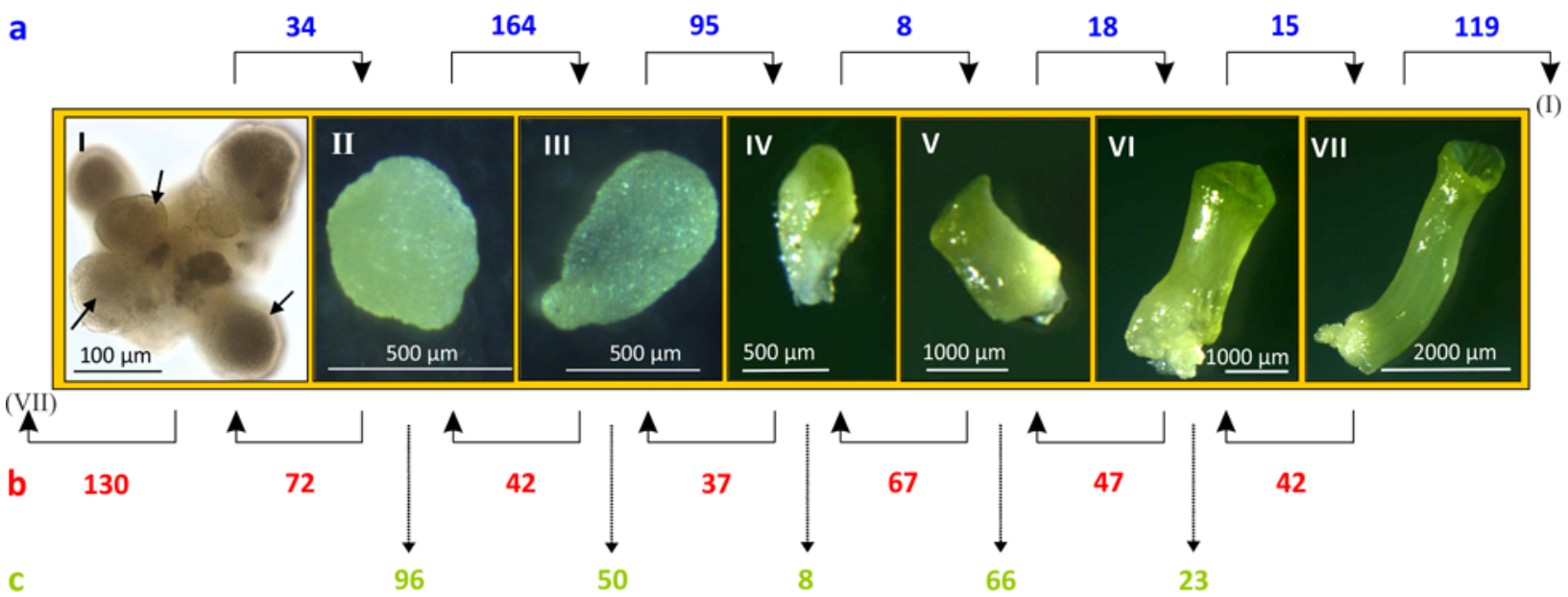

Fig. 2 Seven selected stages (I-VII) of studied embryos in embroygenic cell suspension of Gentiana kurroo and their characteristic number of protein spots. Number of protein spots not observed in the following stage (blue color; $\mathbf{a}$ ), in previous stage (red color; b), and characteristic for particular stage (green color; c). 


\section{Number of protein spots produced by two-dimensional electrophoresis}

Total number of protein spots produced by 2-DE was different and characteristic for the seven stages of G. kurroo somatic embryogenesis analyzed (Fig. 2). The differences ranged from the lowest number of spots presented by stage IV to the highest number of spots presenting in the stage II with over 300 different protein spots. We did not observe the unique differences in the number of produced protein spots between stage III, VI and VII with the number about 545. In the case of Cyclamen persicum, studies revealed that the differing number of spots between particular stages is not large, and globular somatic embryo stage was characterized by 451 protein spots while the torpedo stage was characterized by 460 protein spots [11].

More attention was paid to recognize the number of protein spots characterizing particular stages. Looking on data from the next stage to the previous stage, the highest difference appeared, of course, in the case of globular embryo (stage I) and elongated cotyledonary stage (stage VII) with differences being about 130 spots (Fig. 2). Other stages were characterized by the difference ranging from 37 to 72 protein spots between following and previous stage. However, the focusing on the number of protein spots which differed between previous stage to following one gave the other perspective on the possibilities to recognize the protein markers of a particular somatic embryo stage of G. kurroo. The highest number of not observed protein spots was recognized between stages VII and I stage, over one hundred, but the lowest number of protein spot differences was observed between IV and V stage, just about 10. The Fig. 3 presents the results obtained in case of the stage I, III and VII with the criterion of not find protein spots between the compared stages.

\section{Proteomics of somatic embryogenesis}

Proteomic patterns have been used for various purposes, however, the comparison between particular stages of embryogenesis, embryogenic and non-embryogenic callus during somatic embryogenesis [17] or plant ontogenesis [18] appeared most frequently analyzed in a limited number of previously published papers. In the case of the H99 inbred maize line, the proteome analysis of embryogenic and non-embryogenic callus revealed the existence of 42 proteins spots that were differentially expressed [17]. The protein expression in rice was used for the description of embryogenic and non-embryogenic cultures, as well as isolated embryos from which cultures were initiated. In both types of cultures, the strongest signals were for 56, 54 and $36 \mathrm{kDa}$ proteins, when in case of initial embryos the signals were not present. Only one protein of $54 \mathrm{kDa}$ appeared to be a marker of embryogenesity, and it was not expressed in non-embryogenic tissue [19]. For the pea, two proteins of $45 \mathrm{kDa}$ and $70 \mathrm{kDa}$ were described being the markers of embryogenesity [20]. In the case of cassava, proteome analysis using extended stages of plant development showed that the only a few of the identified proteins are unique to somatic embryos, shoots, adventitious roots and tubers [18].

With the help of 2-DE, the proteins of seven consecutive stages of somatic embryos of G. kurroo were analyzed (Fig. 2). These stages of somatic embryos differ from those usually described in references because of untypical environmental condition of liquid culture in the presence of both plant growth regulators, auxin (2,4-D) and cytokinin (Kinetin). In the case of the last three stages (V, VI, VII) the size (length of embryos) was considered. The Fig. 1 presents the morphological evidences of a particular stage from proembryo to cotyledonary somatic embryo. With the help of the first dimension, the isoelectrofocusing points of isolated proteins from embryos were established. Compare two most distinct stages: globular (I) and cotyledonary (VII) the major difference in the distribution of IEF proteins has been recognized. The first stage of embryo development located studied proteome in majority between $\mathrm{pH}$ values ranging from 6 to 9 , when the total scale was $\mathrm{pH}$ value ranging from 3 to 10 . For the oldest studied stage, the majority of proteins were located between $\mathrm{pH}$ value ranging 6.5 and 8.5. For both
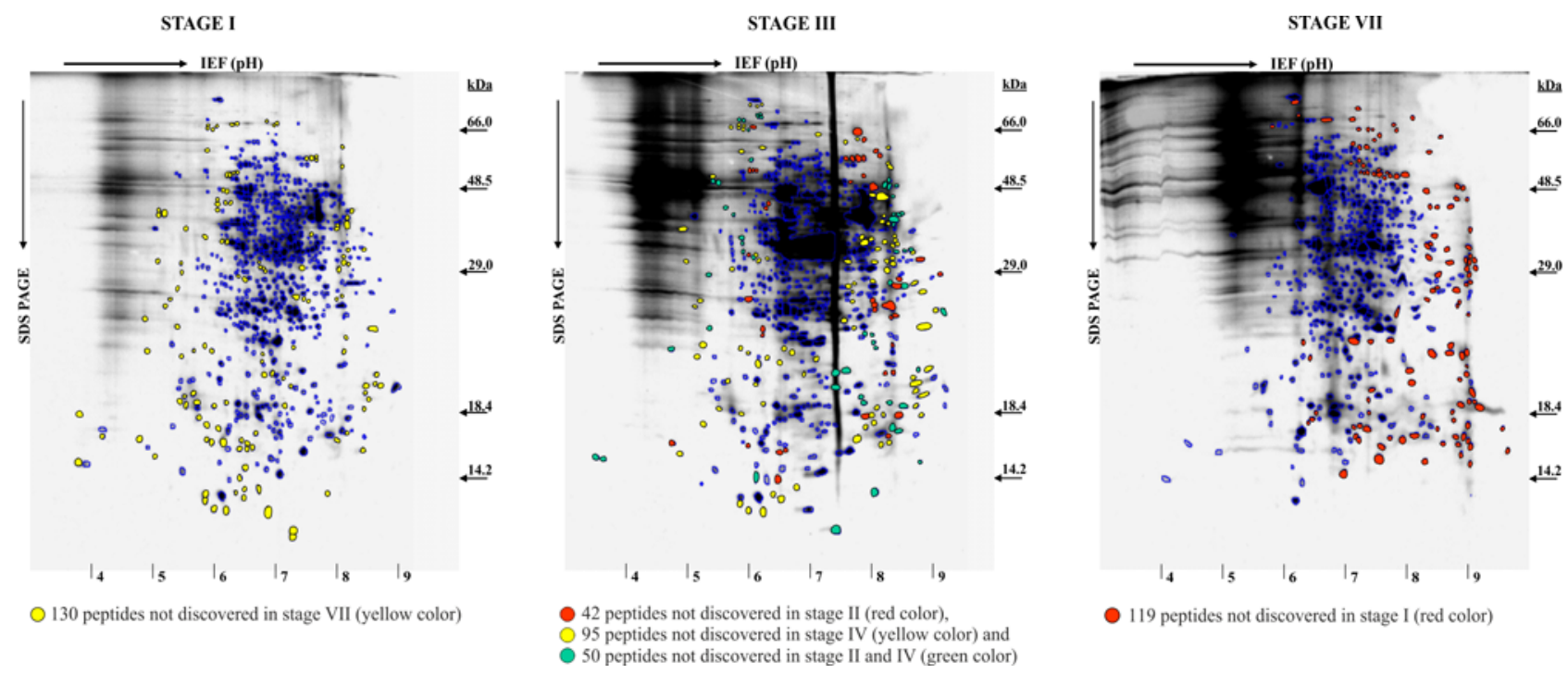

Fig. 3 Number of protein spots and their distribution in 2-DE gel electrophoresis of different stages of somatic embryos. a 130 peptides not discovered in stage VII (yellow color). b 42 peptides not discovered in stage II (red color), 95 peptides not discovered in stage IV (yellow color) and 50 peptides not discovered in stage II and IV (green color). c 119 peptides not discovered in stage I (red color). 
extreme stages, some proteins had acid character just about $\mathrm{pH} 4.0$ or a base character just between $\mathrm{pH}$ values ranging from 9 to 10. Globular and torpedo somatic embryos of $C$. persicum presented IEF of proteins ranging $\mathrm{pH} 5-8$, only [11].

SDS-PAGE gel indicated that the molecular weight of abundant proteins spots for G. kurroo is located between 12 and $70 \mathrm{kDa}$, however, majority of proteins were characterized by $\mathrm{kDa}$ from 20 to 49 . In the embryogenic callus of Crocus sativus, many high abundant protein spots indicated the range of $14-20$ and $30-43 \mathrm{kDa}$ [21]. Describing only three stages: globular, torpedo and cotyledonary of somatic embryos of Coffea arabica two-dimensional electrophoresis analysis revealed a wide range of protein spots ranging between 10 and $160 \mathrm{kDa}$, when $\mathrm{pH}$ value ranging from 3 to

\section{Acknowledgments}

Presented studies were sponsored by Polish State Committee of Scientific Research 3PO4C03723.

\section{Authors' contributions}

The following declarations about authors' contributions to the research have been made: designed research: AN, JJR; performed experiments: AN, JJR; wrote the manuscript: AN, JJR.

\section{References}

1. Barešová H. Centaurium erythraea Rafn.: Micropropagation and the production of secoiridoid glucosides. In: Bajaj YPS, editor. Medicinal and aromatic plants I. Berlin: Springer Berlin Heidelberg; 1988. p. 350-366. (Biotechnology in agriculture and forestry; vol 4). http:// dx.doi.org/10.1007/978-3-642-73026-9_19

2. Miura H. Swertia spp. In: Bajaj YPS, editor. Medicinal and aromatic plants III. Berlin: Springer Berlin Heidelberg; 1991. p. 451-463. (Biotechnology in agriculture and forestry; vol 15). http://dx.doi. org/10.1007/978-3-642-84071-5_27

3. Sharma N, Chandel KPS, Paul A. In vitro propagation of Gentiana kurroo - an indigenous threatened plant of medicinal importance. Plant Cell Tissue Organ Cult. 1993;34(3):307-309. http://dx.doi. org/10.1007/BF00029722

4. Kaur R, Panwar N, Saxena B, Raina R, Bharadwaj SV. Genetic stability in long-term micropropagated plants of Gentiana kurroo - an endangered medicinal plant. J New Seeds. 2009;10(4):236-244. http:// dx.doi.org/10.1080/15228860903303874

5. Mikuła A, Rybczyński JJ. Somatic embryogenesis of Gentiana genus I. The effect of the preculture treatment and primary explant origin on somatic embryogenesis of Gentiana cruciata (L.), G. pannonica (Scop.), and G. tibetica (King). Acta Physiol Plant. 2001;23(1):15-25. http://dx.doi.org/10.1007/s11738-001-0017-x

6. Fiuk A, Rybczyński JJ. Morphogenic capability of Gentiana kurroo Royle seedling and leaf explants. Acta Physiol Plant. 2008;30(2):157166. http://dx.doi.org/10.1007/s11738-007-0104-8

7. Fiuk A, Rybczyński JJ. Factors influencing efficiency of somatic embryogenesis of Gentiana kurroo (Royle) cell suspension. Plant Biotechnol Rep. 2008;2(1):33-39. http://dx.doi.org/10.1007/ s11816-008-0045-8

8. Fiuk A, Rybczyński JJ. The effect of several factors on somatic embryogenesis and plant regeneration in protoplast cultures of Gentiana kurroo (Royle). Plant Cell Tissue Organ Cult. 2007;91(3):263-271. http://dx.doi.org/10.1007/s11240-007-9293-5

9. Rybczyński JJ, Borkowska B, Fiuk A, Gawrońska H, Śliwińska E, Mikuła A. Effect of sucrose concentration on photosynthetic activity of in vitro cultures Gentiana kurroo (Royle) germlings. Acta Physiol Plant. 2007;29(5):445-453. http://dx.doi.org/10.1007/s11738-007-0054-1

10. Tonietto Â, Sato JH, Teixeira JB, Souza EM, Pedrosa FO, Franco OL,
10 [10]. All these studies confirm earlier published results indicating quantitative and qualitative protein variation between proembryo and well-developed cotyledonary stage because of mechanisms involved in differentiation against development and maturation, respectively [12].

Our results concerning protein analysis of G. kurroo somatic embryos have shown that proposed seven stages of embryogenesis (I-VII stages) can be utilized for estimation of the correlation between protein expression and gene involved in the development of somatic embryos. Moreover, they could be used for supporting the progress in studies of genetic and physiological controls of somatic embryogenesis in such model plants as Arabidopsis thaliana and Medicago truncatula.

et al. Proteomic analysis of developing somatic embryos of Coffea arabica. Plant Mol Biol Rep. 2012;30(6):1393-1399. http://dx.doi. org/10.1007/s11105-012-0425-7

11. Bian F, Zheng C, Qu F, Gong X, You C. Proteomic analysis of somatic embryogenesis in Cyclamen persicum Mill. Plant Mol Biol Rep. 2010;28(1):22-31. http://dx.doi.org/10.1007/s11105-009-0104-5

12. Sallandrouze A, Faurobert M, El Maataoui M, Espagnac H. Twodimensional electrophoretic analysis of proteins associated with somatic embryogenesis development in Cupressus sempervirens L. Electrophoresis. 1999;20(4-5):1109-1119. http://dx.doi.org/10.1002/ (SICI)1522-2683(19990101)20:4/5<1109::AID-ELPS1109>3.0.CO;2-4

13. Petrova M, Stoilova T, Zagorska N. Isoenzyme and protein patterns of in vitro micropropagated plantlets of Gentiana lutea L. after application of various growth regulators. Biotechnol Biotechnol Equip. 2006;20(1):15-19. http://dx.doi.org/10.1080/13102818.2006.10817297

14. Hochstrasser DF, Harrington MG, Hochstrasser AC, Miller MJ, Merril CR. Methods for increasing the resolution of two-dimensional protein electrophoresis. Anal Biochem. 1988;173(2):424-435. http://dx.doi. org/10.1016/0003-2697(88)90209-6

15. Heukeshoven J, Dernick R. Simplified method for silver staining of proteins in polyacrylamide gels and the mechanism of silver staining. Electrophoresis. 1985;6(3):103-112. http://dx.doi.org/10.1002/ elps. 1150060302

16. Domżalska L, Kędracka-Krok S, Rybczyński JJ. Proteomic changes in Gentiana cruciata L. cell suspension during adaptation to osmotic stress in cryopreservation protocol. In: Pukacki PM, editor. Proceeding of the 17th cold hardiness seminar in Poland. Kórnik: Institute of Dendrology of the Polish Academy of Sciences; 2011. p. 44-52.

17. Sun L, Wu Y, Zou H, Su S, Li S, Shan X, et al. Comparative proteomic analysis of the H99 inbred maize (Zea mays L.) line in embryogenic and non-embryogenic callus during somatic embryogenesis. Plant Cell Tissue Organ Cult. 2013;113(1):103-119. http://dx.doi.org/10.1007/ s11240-012-0255-1

18. Li K, Zhu W, Zeng K, Zhang Z, Ye J, Ou W, et al. Proteome characterization of cassava (Manihot esculenta Crantz) somatic embryos, plantlets and tuberous roots. Proteome Sci. 2010;8(1):10. http://dx.doi. org/10.1186/1477-5956-8-10

19. Chen LJ, Luthe DS. Analysis of proteins from embryogenic and nonembryogenic rice (Oryza sativa L.) calli. Plant Sci. 1987;48(3):181-188. http://dx.doi.org/10.1016/0168-9452(87)90088-4

20. Stirn S, Jacobsen HJ. Marker proteins for embryogenic differentiation patterns in pea callus. Plant Cell Rep. 1987;6(1):50-54. http://dx.doi. org/10.1007/BF00269738

21. Sharifi G, Ebrahimzadeh H, Ghareyazie B, Gharechahi J, Vatankhah E. Identification of differentially accumulated proteins associated with embryogenic and non-embryogenic calli in saffron (Crocus sativus L.). Proteome Sci. 2012;10(1):3. http://dx.doi.org/10.1186/1477-5956-10-3 